\title{
Cetirizine use in childhood: an update of a friendly 30-year drug
}

\author{
Giuseppe Fabio Parisi ${ }^{*}$ (D), Salvatore Leonardi ${ }^{1}$, Giorgio Ciprandi ${ }^{2}$, Angelo Corsico ${ }^{3}$, Amelia Licari ${ }^{4}$, \\ Michele Miraglia del Giudice ${ }^{5}$, Diego Peroni ${ }^{6}$, Carmelo Salpietro ${ }^{7}$ and Gian Luigi Marseglia ${ }^{4}$
}

\begin{abstract}
Cetirizine is a second-generation antihistamine, derived from the metabolism of hydroxyzine, highly specific for the $\mathrm{H} 1$ receptors, and with marked antiallergic properties. Although its history began more than 30 years ago, it remains one of the most used drugs in children with a leading role in the medical care of children with allergic diseases. Cetirizine use is licensed for paediatric patients for the treatment of allergic rhinitis, and chronic spontaneous urticaria, in Europe in children older than 2 years old and in the USA in children older than 6 months old. This review provides a practical update on the use of cetirizine in children and adolescents.
\end{abstract}

Keywords: Cetirizine, Antihistamines, Histamine, H1 receptors, Children, Adolescents, Pregnancy, Lactation

\section{Background}

Cetirizine is a second-generation antihistamine derived from the metabolism of hydroxyzine, with high specificity for the $\mathrm{H} 1$ receptors and antiallergic properties [1]. Although its history began more than 30 years ago, it remains one of the most used drugs in children, accounting for about $9 \%$ of all paediatric prescriptions [2]. Cetirizine is an orally administered drug that reaches a peak concentration about $2 \mathrm{~h}$ after its administration in children; it is then only slightly metabolized in the liver and then eliminated by renal excretion [3]. In children, the cetirizine half-life is reduced because of their increased hepatic metabolism; this may justify the occasional need to double the daily dose. Adolescents could take cetirizine once a day, as well as adults [1]. Cetirizine exceeds the blood-brain barrier in minimal quantities and, for this reason, does not cause the classic sedative effects associated with other antihistamines [4]. In allergic subjects, the drug acts to antagonize the secretion of histamine, inhibit the recruitment of eosinophils, release

\footnotetext{
${ }^{*}$ Correspondence: giuseppeparisi88@hotmail.it

${ }^{1}$ Department of Clinical and Experimental Medicine, University of Catania, Via Santa Sofia, 78, 95123 Catania, Italy
}

Full list of author information is available at the end of the article leukotriene B4, and decrease the expression of the vascular cell adhesion molecule (VCAM-1), thus also exerting a powerful anti-inflammatory effect [3].

Nowadays, cetirizine use is licensed for children and adolescents for the treatment of allergic rhinitis and chronic spontaneous urticaria (CSU); children should be older than 2 years old, although the US Food and Drug Administration (FDA) licensed cetirizine also for children aged over 6 months $[5,6]$. Cetirizine is administered at the dose of $0.25 \mathrm{mg} / \mathrm{kg} /$ day $(1 \mathrm{drop}=0.5 \mathrm{mg}$ ) [5].

This review summarizes the evidence regarding the 30 -year-history of cetirizine. The use of the drug during pregnancy and lactation will also be evaluated.

\section{Safety profile}

Antihistamines, especially first-generation ones, have central effects that cause drowsiness, tiredness, increased appetite, or worsening of cognitive functions (Table 1). They may also have antimuscarinic, antiadrenergic, and antiserotoninergic activity that may cause vision disorders, dry mouth, tachycardia, and confusion [7]. The use of first-generation antihistamines that have sedative effects is not anymore recommended in children. Some antihistamines, particularly ebastine and mizolastine, can cause a significant prolongation of the QT interval on an

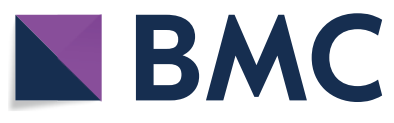

c) The Author(s) 2020. This article is licensed under a Creative Commons Attribution 4.0 International License, which permits use, sharing, adaptation, distribution and reproduction in any medium or format, as long as you give appropriate credit to the original author(s) and the source, provide a link to the Creative Commons licence, and indicate if changes were made. The images or other third party material in this article are included in the article's Creative Commons licence, unless indicated otherwise in a credit line to the material. If material is not included in the article's Creative Commons licence and your intended use is not permitted by statutory regulation or exceeds the permitted use, you will need to obtain permission directly from the copyright holder. To view a copy of this licence, visit http://creativeco mmons.org/licenses/by/4.0/. The Creative Commons Public Domain Dedication waiver (http://creativecommons.org/publicdomain/ zero/1.0/) applies to the data made available in this article, unless otherwise stated in a credit line to the data. 


\begin{tabular}{ll}
$\begin{array}{l}\text { Table } 1 \text { Most common } \\
\text { antihistamines }\end{array}$ & first and \\
\hline First generation & Second generation \\
\hline Diphenhydramine & Cetirizine \\
Clemastine & Levocetirizine \\
Clorphenamine & Ketotifen \\
Dimetindene & Loratadine \\
Hydroxyzine & Desloratadine \\
Promethazine & Rupatadine \\
Alimemazine & Ebastine \\
Cyproheptadine & Bilastine \\
& Fexofenadine \\
\hline
\end{tabular}

electrocardiogram, which can cause severe arrhythmias, even life-threatening, such as torsade de point [8].

An original report published in 2017 showed that the use of antihistamines is associated with severe and unexpected adverse drug reactions (ADRs), and 400 patients had a fatal outcome. More than half of deaths (205 cases) involved children under 2 years of age, and 74 of them involved suspected drugs not licensed in that age-group. One of the most significant points that was highlighted was the finding that serious ADRs had been correlated with off-label use concerning the indication, age group, and overdose [9].

Cetirizine appears to be well tolerated in children. The most common side effects (e.g., drowsiness, headache, pharyngitis, abdominal pain, diarrhea, coughing) do not seem to be more frequent in clinical trials that have evaluated the efficacy and safety of cetirizine compared to placebo or other antihistamines [10-12]. The tolerability of the drug is comparable also to the newer anti H1, for example bilastine or levocetirizine [13]. Regarding somnolence, this appears to be dose-related, with an incidence of approximately $2-4 \%$ of patients compared to $1 \%$ of placebo patients. Interestingly, children tolerate better this adverse effect than adults [1]. Furthermore, cetirizine does not appear to be associated with significant cardiac alterations such as changes in the QT interval in pediatric populations [14], and even doses 4 times higher than the recommended dose have not been associated with significant toxicity affecting the heart or central nervous system [15]. Finally, recently, a new topical ophthalmic solution (0.24\%) was approved by the FDA for the treatment of allergic conjunctivitis with a demonstrated safety profile in children older than 2 years old [6].

\section{Conventional clinical indications} Allergic rhinitis and conjunctivitis

Histamine is the most potent mediator that is released during the early phase of an allergic reaction and causes itching, sneezing, rhinorrhoea, and nasal congestion. The Allergic Rhinitis and its Impact on Asthma (ARIA) guidelines recommend using second-generation oral antihistamines for both seasonal (SAR) and perennial (PAR) rhinitis; these molecules represent the most suitable preparations to treat allergic rhinitis because of their already mentioned 'antiallergic-anti-inflammatory' activity and excellent safety profile. Such drugs can be used as needed if the symptoms are occasional. In SAR, treatment with anti-H1 antihistamines could be started before exposure to the allergens to downregulate constitutive $\mathrm{H} 1$ receptor activity and shift the equilibrium from the active form of the $\mathrm{H} 1$ receptor to the inactive form, thus preventing the massive release of histamine by mast cells; this treatment has to be continued for the entire duration of pollination. In PAR, the treatment should instead be modulated based on clinical symptoms, and it has the dual purpose of controlling the persistent mucosal inflammation that reduces the inflammatory mucosal infiltrate and adhesion molecule expression [16, 17].

Among antihistamines, cetirizine has a relatively higher affinity and selectivity for $\mathrm{H} 1$ receptors, which confers a more potent, faster onset, and longer duration of action with even anti-inflammatory properties independent of its anti-H1 effects [18, 19]. Ciprandi et al. [20] demonstrated that cetirizine exerts a significant anti-inflammatory activity in children with PAR decreasing the nasal levels of interleukin (IL)-4 and IL-8. Similar results were obtained by Uguz and colleagues [21], who demonstrated that cetirizine induces a shift in the Th1/Th2 cytokine balance towards a Th1 response, increasing the production of interferon (IFN)-gamma and IL-10. From a clinical point of view, cetirizine was shown to be more effective when compared with placebo in the treatment of SAR with a significant reduction in the number of days characterized by the absence of symptoms assessed by questionnaires [14, 22, 23]. Furthermore, the efficacy of cetirizine appears to be immediate (within $24 \mathrm{~h}$ ) and lasting over time when compared with first-generation antihistamines and is not burdened by significant side effects [24]. Also, when compared with other second-generation antihistamines (see Table 1), cetirizine seems to be more effective: Lee et al. showed that the 12-week treatment program with cetirizine was more effective than levocetirizine [25], and recently, in a randomized, placebocontrolled study, a better effect of cetirizine was found in the treatment of allergic rhinitis when compared with loratadine [26]. Concerning PAR, the effect of cetirizine has also been compared to montelukast. Although both products appear to be effective in reducing symptoms compared to placebo, cetirizine offers better results in improving nasal itching [27]. Furthermore, clinical studies demonstrate the importance of long-term cetirizine 
therapy: in children with dust mite allergy, treatment for at least 6 months results in a significant reduction in the prescription of other drugs (e.g., inhaled corticosteroids, beta2-agonists, antibiotics) compared to placebo [28]. In the same category of children, it has been shown that treatment for at least 3 years with cetirizine is associated with a reduction of new allergic sensitizations [29].

Regarding dosage, it was confirmed that $10 \mathrm{mg}$ per day in children over 6 years (divided into two administrations if less than 12 years) is better when compared with $5 \mathrm{mg}$ in terms of symptom reduction, both concerning rhinitis and conjunctivitis. The administration of $5 \mathrm{mg}$ is only useful for the reduction of sneezing [30]. Table 2 summarizes the evidences on the efficacy of cetirizine in the treatment of allergic rhinitis and conjunctivitis.

\section{Chronic spontaneous urticaria (CSU)}

Anti-H1 antihistamines are effective at reducing itchiness number, size, and duration of wheals and erythema in patients with acute or chronic urticaria. The current guidelines recommend the use of second-generation molecules for their tolerability and safety profile. In CSU, progressively increasing the dose of second-generation H1-antihistamines up to fourfold higher than the recommended dose, or using a combination of two different second-generation antihistamines, is suggested when there is treatment failure using standard doses [31, 32].

A double-blinded, multicentre study performed on 62 children aged 2-6 years showed that cetirizine was safe and effective in the treatment of urticaria symptoms (erythema, papules, edema, itching) when compared with oxatomide [12]. Furthermore, cetirizine seems to be effective in 12-24 month-old children with atopic dermatitis in the prevention of acute urticaria [33]. A recently published case report showed a successful treatment of severe CSU in a 14-year-old boy who was supposed to be unresponsive to omalizumab since its CSU was not IgE-mediated with conventional treatment (cetirizine, montelukast, systemic steroids, and dietary restriction) [34]. Regarding the dose to be administered, already Komeyoshi et al. [35] had shown that in patients who had responded poorly to therapy with the initial dosage, doubling the dose of cetirizine resulted in improved symptom control. These findings were confirmed later by Okubo et al. [36] in a prospective, randomized, nonblinded study they showed that doubling the cetirizine dose led to an improvement in the quality of life and severity of wheal and itching in $64.7 \%$ of treated patients. Recent data support the safety of the drug even when the dose is up to fourfold or prolonged administered [37, 38].

\section{Unconventional uses \\ Atopic eczema}

Although their use is controversial, antihistamines are commonly used in the treatment of itching associated with atopic dermatitis. The National Institute for Health and Care Excellence (NICE) guidelines for treating atopic eczema suggest a 1-month trial of a non-sedating antihistamine in children with severe itching; this treatment may be continued, if successful, while symptoms persist, but this treatment regimen should be reviewed every 3 months [39].

The historical double-blinded, randomized, placebocontrolled ETAC trial evaluated the efficacy of cetirizine

Table 2 Summary of evidence on the efficacy of cetirizine in the treatment of allergic rhinitis

\begin{tabular}{|c|c|c|c|}
\hline References & Disease & Subjects & Main results \\
\hline Ciprandi et al. [20] & Perennial allergic rhinitis & 20 children & Decreasing of nasal IL-4 and IL-8 levels \\
\hline Uguz et al. [21] & Perennial allergic rhinitis & 13 children & Increasing the production of IFN-gamma and IL-10 \\
\hline Allegra et al. [22] & Seasonal allergic rhinitis & 107 children aged $2-6$ years & $\begin{array}{l}\text { Improvement in sneezing, rhinorrhea, nasal obstruction, nasal and } \\
\text { ocular pruritus than placebo }\end{array}$ \\
\hline Masi et al. [23] & Seasonal allergic rhinitis & 124 children aged $6-12$ years & $\begin{array}{l}\text { Improvement in sneezing, rhinorrhea, nasal obstruction, nasal and } \\
\text { ocular pruritus than placebo }\end{array}$ \\
\hline Pearlman et al. [14] & Seasonal allergic rhinitis & 209 children aged 6-11 years & $\begin{array}{l}\text { Improvement in sneezing, nasal discharge, itchy eyes, itchy nose or } \\
\text { mouth, conjunctivitis, nasal congestion than placebo }\end{array}$ \\
\hline Nayak et al. [25] & Seasonal allergic rhinitis & 683 children aged $6-11$ years & Improvement in TSSC than loratadine and placebo \\
\hline Lee et al. [26] & Perennial allergic rhinitis & 74 children aged $6-12$ years & Improvement in TSS than levocetirizine and placebo \\
\hline Chen et al. [27] & Perennial allergic rhinitis & 60 children aged 2-6 years & $\begin{array}{l}\text { Improvement in eosinophil percentage in nasal smears, PRQLQ and } \\
\text { TSS. Cetirizine better than montelukast for itching }\end{array}$ \\
\hline Ciprandi et al. [28] & Rhinitis and/or mild asthma & 10 children & $\begin{array}{l}\text { Improvement in symptoms and reduction of drug consumption than } \\
\text { placebo }\end{array}$ \\
\hline Ciprandi et al. [29] & Mite allergy & 20 children & Lower incidence of new sensitisations \\
\hline Pearlman et al. [30] & Seasonal allergic rhinitis & 209 children aged 6-11 years & Improvement in TSS than placebo \\
\hline
\end{tabular}

TSSC total symptom score complex, TSS total symptom score, PRQLQ paediatric rhinoconjunctivitis quality of life questionnaire 
in children with atopic dermatitis in the prevention of asthma. They showed that cetirizine delays or prevents the development of asthma in children with atopic dermatitis sensitized to grass pollen $(R R=0.5, p=0.002)$ and, to a lower degree $(R R=0.6, p=0.005)$, house dust mites when compared to placebo-treated controls [40]. In the same cohort of patients, the consumption of drugs for the same conditions was studied, demonstrating that other oral H1-antihistamines were significantly more often used in the placebo group than in the cetirizine group $(24.9 \%$ vs. $18.6 \%, p=0.03)$. Moreover, cetirizine reduced the amount and duration of moderate-to-strong topical corticosteroids needed to treat subjects with atopic eczema [41]. Recently, a Cochrane review evaluated the efficacy of oral $\mathrm{H} 1$ antihistamines as an add-on therapy to topical treatment for eczema, highlighting how, despite the scientific evidence being qualitatively limited, cetirizine was burdened by fewer side effects and less need for additional H1-antihistamines in case of eczema flare compared with other antihistamines used as an add-on therapy [42].

\section{Asthma}

Antihistamines should not be considered a therapeutic option in case of asthma but may have a role in treating comorbidities such as allergic rhinitis and in that way exert an indirect positive impact on asthma control. In fact, during allergic rhinitis and asthma, the upper and lower airways are affected by a common inflammatory process that can be sustained and amplified by interconnected mechanisms. Allergic rhinitis and non-specific vasomotor rhinitis are some of the most critical risk factors for the onset of asthmatic disease, and they are therefore important aggravating factors [43]. Thus, therapy with anti-H1 antihistamines confers an additional benefit in the control of asthmatic symptoms in subjects with concomitant allergic rhinitis and bronchial asthma [44].

Studies that evaluated the efficacy of cetirizine in patients with mild or moderate asthma were performed in adult populations in which allergic rhinitis coexisted. These studies, many of which were randomized and placebo-controlled, showed that doses ranging from 10 to $30 \mathrm{mg}$ of cetirizine determine an improvement in asthma symptoms (but not always in pulmonary function tests), especially when the treatment reached 5-6 weeks [45-49].

\section{Cetirizine during pregnancy and lactation}

It has been observed that about $25 \%$ of pregnant women suffer from allergic diseases, mainly urticaria, and rhinoconjunctivitis, which need to be treated with antihistamines to reduce symptoms and improve quality of life.
Already in 2008, Weber-Schoendorfer and Shaefer evaluated a cohort of 196 pregnant women and showed that exposure to cetirizine in the first trimester of pregnancy was not associated with an increased risk of abortions or fetal malformations [50]. These data on safety have also been confirmed recently in observational cohort studies and meta-analyses [51, 52].

Regarding breastfeeding, a study conducted with telephone interviews reported that breastfed babies whose mothers took antihistamines were irritable, but none of these symptoms were relevant, so no medical consultation was necessary [53]. The British Society for Allergy and Clinical Immunology recommends cetirizine as an antihistamine of choice in the case of breastfeeding at the minimum possible dose and for the shortest possible time. In fact, elevated doses or prolonged use can cause excessive drowsiness or, on the contrary, excessive irritability in breast-fed children, especially if they are administered concomitantly with sympathomimetics such as pseudoephedrine [54].

\section{Conclusions}

Cetirizine is a second-generation antihistamine that retains a leading role in the effective treatment of children with allergic diseases. The evidence of 30-yearclinical-experience support this drug above all as the first choice for good safety data during pregnancy and breastfeeding.

\section{Abbreviations \\ ADRs: Adverse drug reactions; ARIA: Allergic Rhinitis and its Impact on Asthma; CSU: Chronic spontaneous urticarial; FDA: Food and Drug Administration; IFN: Interferon; IL: Interleukin; NICE: National Institute for Health and Care Excel- lence; PAR: Perennial allergic rhinitis; SAR: Seasonal allergic rhinitis; TSSC: Total symptom score complex; VCAM-1:Vascular cell adhesion molecule.}

\section{Acknowledgements \\ Not applicable.}

\section{Authors' contributions}

GP and GLM developed the original idea and the final revision, GFP and SL wrote the manuscript, AC, AM, MMG, DP and CS revised the manuscript and contributed to English revision and references update. All authors provided substantial contributions to the conception or design of the work, or the acquisition, analysis, or interpretation of data for the paper, revised the manuscript for important intellectual content, approved the final version, and agreed to be accountable for all aspects of the work. All authors read and approved the final manuscript.

\section{Funding}

This paper was realized with the support of Dompé Farmaceutici S.p.A. Italy through an unrestricted grant.

Availability of data and materials

Not applicable.

Ethics approval and consent to participate Not applicable. 


\section{Consent for publication \\ Not applicable.}

\section{Competing interests}

The authors declare that they participated in an advisory board organized by Dompé Farmaceutici S.p.A. Italy concerning the role of antihistamines in clinical practice. AGC is an Associate Editor of Multidisciplinary Respiratory Medicine.

\section{Author details \\ 1 Department of Clinical and Experimental Medicine, University of Catania, Via Santa Sofia, 78, 95123 Catania, Italy. ${ }^{2}$ Allergy Clinic, Casa di Cura Villa Montal- legro, Genoa, Italy. ${ }^{3}$ Pulmonology Clinic, Foundation IRCCS Policlinico San Matteo, University of Pavia, Pavia, Italy. ${ }^{4}$ Department of Pediatrics, Foundation IRCCS Policlinico San Matteo, University of Pavia, Pavia, Italy. ${ }^{5}$ Department of Woman, Child and of General and Specialized Surgery, University of Cam- pania Luigi Vanvitelli, Naples, Italy. ${ }^{6}$ U.O. Pediatria, Azienda Ospedaliero-Uni- versitaria Pisana, Scuola di Specializzazione in Pediatria, University of Pisa, Pisa, Italy. ${ }^{7}$ Unit of Pediatric Genetics and Immunology, Department of Pediatrics, University of Messina, Messina, Italy.}

Received: 23 November 2019 Accepted: 17 February 2020

Published online: 26 February 2020

\section{References}

1. Curran MP, Scott LJ, Perry CM. Cetirizine. A review of its use in allergic disorders. Drugs. 2004;64:523-61.

2. Piovani D, Clavenna A, Bonati M, PeFAB group. Review of Italian primary care paediatricians identifies 38 commonly prescribed drugs for children. Acta Paediatr. 2014;103(12):e532-7. https://doi.org/10.1111/apa.12783 (Epub 2014 Oct 2).

3. Portnoy JM, Dinakar C. Review of cetirizine hydrochloride for the treatment of allergic disorders. Expert Opin Pharmacother. 2004;5:125-35.

4. Gupta A, Chatelain P, Massingham R, Jonsson EN, Hammarlund-Udenaes $M$. Brain distribution of cetirizine enantiomers: comparison of three different tissue-to-plasma partition coefficients: $K(p), K(p, u)$, and $K(p, u u)$. Drug Metab Dispos. 2006;34(2):318-23.

5. Banca dati Agenzia Italiana del Farmaco (AIFA). https://farmaci.agenziafar maco.gov.it/bancadatifarmaci/home. Accessed Sept 2019.

6. Food and Drug Administration (FDA). https://www.fda.gov/drugs. Accessed Dec 2019.

7. Yanai K, Rogala B, Chugh K, Paraskakis E, Pampura AN, Boev R. Safety considerations in the management of allergic diseases: focus on antihistamines. Curr Med Res Opin. 2012;28(4):623-42.

8. Poluzzi E, Raschi E, Motola D, Moretti U, De Ponti F. Antimicrobials and the risk of torsades de pointes: the contribution from data mining of the US FDA Adverse Event Reporting System. Drug Saf. 2010;33(4):303-14.

9. Motola D, Donati M, Biagi C, Calamelli E, Cipriani F, Melis M, et al. Safety profile of $\mathrm{H1}$-antihistamines in pediatrics: an analysis based on data from VigiBase. Pharmacoepidemiol Drug Saf. 2017;26(10):1164-71.

10. Simons FE. Prospective, long-term safety evaluation of the $\mathrm{H} 1$-receptor antagonist cetirizine in very young children with atopic dermatitis. ETAC Study Group. Early treatment of the atopic child. J Allergy Clin Immunol. 1999;104(2 Pt 1):433-40.

11. Simons FE, Silas P, Portnoy JM, Catuogno J, Chapman D, Olufade AO. Safety of cetirizine in infants 6 to 11 months of age: a randomized, double-blind, placebo-controlled study. J Allergy Clin Immunol. 2003;111(6):1244-8

12. La Rosa M, Leonardi S, Marchese G, Corrias A, Barberio G, Oggiano N, Grimaldi I. Double-blind multicenter study on the efficacy and tolerability of cetirizine compared with oxatomide in chronic idiopathic urticaria in preschool children. Ann Allergy Asthma Immunol. 2001;87(1):48-53.

13. Kuna P, Jurkiewicz D, Czarnecka-Operacz MM, Pawliczak R, Woroń J, Moniuszko M, Emeryk A. The role and choice criteria of antihistamines in allergy management-expert opinion. Postep Dermatol Alergol. 2016;33(6):397-410. https://doi.org/10.5114/pdia.2016.63942 (Epub 2016 Dec 2).

14. Pearlman DS, Lumry WR, Winder JA, Noonan MJ. Once-daily cetirizine effective in the treatment of seasonal allergic rhinitis in children aged 6 to 11 years: a randomized, double-blind, placebo-controlled study. Clin Pediatr. 1997;36(4):209-15.

15. Spiller HA, Villalobos D, Benson BE, Krenzelok EP, Anderson AD. Retrospective evaluation of cetirizine (zyrtec) ingestion. J Toxicol Clin Toxicol. 2002;40(4):525-6.

16. Brożek JL, Bousquet J, Agache l, et al. Allergic rhinitis and its impact on asthma (ARIA) guidelines-2016 revision. J Allergy Clin Immunol. 2017; 140(4):950-8.

17. Licari A, Ciprandi G, Marseglia A, et al. Current recommendations and emerging options for the treatment of allergic rhinitis. Expert Rev Clin Immunol. 2014;10:1337-47.

18. Gillard M, Christophe B, Wels B, Peck M, Massingham R, Chatelain P. H1 antagonists: receptor affinity versus selectivity. Inflamm Res. 2003:52(Suppl 1):S49-50.

19. Fadel R, Herpin-Richard N, Rihoux JP, Henocq E. Inhibitory effect of cetirizine $2 \mathrm{HCl}$ on eosinophil migration in vivo. Clin Allergy. 1987;17(4):373-9.

20. Ciprandi G, Tosca MA, Milanese M, et al. Cetirizine reduces cytokines and inflammatory cells in children with perennial allergic rhinitis. Eur Ann Allergy Clin Immunol. 2004;37:237-40.

21. Uğuz A, Sanlioğlu S, Yüzbey S, Coşkun M, Yeğin O. The effect of cetirizine on IFN-gamma and IL-10 production in children with allergic rhinitis. Turk J Pediatr. 2005;47(2):111-5.

22. Allegra $L$, Paupe J, Wieseman HG, Baelde Y. Cetirizine for seasonal allergic rhinitis in children aged 2-6 years. A double-blind comparison with placebo. Pediatr Allergy Immunol. 1993;4(3):157-61.

23. Masi M, Candiani R, van de Venne H. A placebo-controlled trial of cetirizine in seasonal allergic rhino-conjunctivitis in children aged 6 to 12 years. Pediatr Allergy Immunol. 1993;4(4 Suppl):47-52.

24. Tinkelman DG, Kemp J, Mitchell DQ, Galant SP. Treatment of seasonal allergic rhinitis in children with cetirizine or chlorpheniramine: a multicenter study. Pediatr Asthma Allergy. 1996;10(1):9-17.

25. Nayak AS, Berger WE, LaForce CF, Urdaneta ER, Patel MK, Franklin KB, Wu MM. Randomized, placebo-controlled study of cetirizine and loratadine in children with seasonal allergic rhinitis. Allergy Asthma Proc. 2017;38(3):222-30. https://doi.org/10.2500/aap.2017.38.4050.

26. Lee CF, Sun HL, Lu KH, Ku MS, Lue KH. The comparison of cetirizine, levocetirizine and placebo for the treatment of childhood perennial allergic rhinitis. Pediatr Allergy Immunol. 2009;20(5):493-9.

27. Chen ST, Lu KH, Sun HL, Chang WT, Lue KH, Chou MC. Randomized placebo-controlled trial comparing montelukast and cetirizine for treating perennial allergic rhinitis in children aged 2-6 yr. Pediatr Allergy Immunol. 2006;17(1):49-54.

28. Ciprandi G, Tosca M, Passalacqua G, Canonica GW. Long-term cetirizine treatment reduces allergic symptoms and drug prescriptions in children with mite allergy. Ann Allergy Asthma Immunol. 2001;87(3):222-6.

29. Ciprandi G, Frati F, Marcucci F, Sensi L, Milanese M, Tosca MA. Long-term cetirizine treatment may reduce new sensitisations in allergic children: a pilot study. Eur Ann Allergy Clin Immunol. 2003;35(6):208-11.

30. Pearlman DS, Lumry WR, Winder JA, et al. Once-daily cetirizine effective in the treatment of seasonal allergic rhinitis in children aged 6 to 11 years: a randomized, double-blind, placebo-controlled study. Clin Pediatr. 1997;36:209-15.

31. Zuberbier T, Aberer W, Asero R, Abdul Latiff AH, Baker D, Ballmer-Weber $B$, et al. The EAACI/GA2LEN/EDF/WAO guideline for the definition, classification, diagnosis and management of urticaria. The 2017 revision and update. Allergy. 2018;73(7):1393-414.

32. Manti S, Salpietro C, Cuppari C. Antihistamines: recommended dosagedivergence between clinical practice and guideline recommendations. Int Arch Allergy Immunol. 2019;178(1):93-6.

33. Simons FE. Prevention of acute urticaria in young children with atopic dermatitis. J Allergy Clin Immunol. 2001;107(4):703-6.

34. Poddighe D, Brambilla I, Licari A, Marseglia GL. Paediatric severe chronic spontaneous urticaria: successful management through conventional drug therapy. BMJ Case Rep. 2019. https://doi.org/10.1136/bcr-2019230925.

35. Kameyoshi Y, Tanaka T, Mihara S, Takahagi S, Niimi N, Hide M. Increasing the dose of cetirizine may lead to better control of chronic idiopathic urticaria: an open study of 21 patients. Br J Dermatol. 2007;157(4):803-4.

36. Okubo Y, Shigoka Y, Yamazaki M, Tsuboi R. Double dose of cetirizine hydrochloride is effective for patients with urticaria resistant: a 
prospective, randomized, non-blinded, comparative clinical study and assessment of quality of life. J Dermatol Treat. 2013;24(2):153-60.

37. Cataldi M, Maurer M, Taglialatela M, Church MK. Cardiac safety of secondgeneration $\mathrm{H}_{1}$-antihistamines when updosed in chronic spontaneous urticaria. Clin Exp Allergy. 2019. https://doi.org/10.1111/cea.13500.

38. Elzen MT, Os-Medendorp H, Brink I, et al. Effectiveness and safety of antihistamines up to fourfold or higher in treatment of chronic spontaneous urticaria. Clin Transl Allergy. 2017;7:4. https://doi.org/10.1186/s1360 1-017-0141-3.

39. National Institute for Health and Clinical Excellence. Atopic eczema in children: Management of atopic eczema in children from birth up to the age of 12 years. 2007. http://www.nice.org.uk/guidance/CG57. Accessed Dec 2019.

40. Warner JO, ETAC Study Group, Early Treatment of the Atopic Child. A double-blinded, randomized, placebo-controlled trial of cetirizine in preventing the onset of asthma in children with atopic dermatitis: 18 months' treatment and 18 months' posttreatment follow-up. J Allergy Clin Immunol. 2001;108(6):929-37.

41. Diepgen TL, Early Treatment of the Atopic Child Study Group. Long-term treatment with cetirizine of infants with atopic dermatitis: a multi-country, double-blind, randomized, placebo-controlled trial (the ETAC trial) over 18 months. Pediatr Allergy Immunol. 2002;13(4):278-86.

42. Matterne U, Böhmer MM, Weisshaar E, Jupiter A, Carter B, Apfelbacher $\mathrm{CJ}$. Oral $\mathrm{H} 1$ antihistamines as 'add-on' therapy to topical treatment for eczema. Cochrane Database Syst Rev. 2019;1:CD012167.

43. Ciprandi G, Caimmi D, Miraglia Del Giudice M, La Rosa M, Salpietro C, Marseglia GL. Recent developments in United airways disease. Allergy Asthma Immunol Res. 2012;4(4):171-7.

44. Corren J, Manning BE, Thompson SF, et al. Rhinitis therapy and the prevention of hospital care for asthma: a case-control studi. J Allergy Clin Immunol. 2004:113:415-9.

45. Aaronson DW. Evaluation of cetirizine in patients with allergic rhinitis and perennial asthma. Ann Allergy Asthma Immunol. 1996;76(5):440-6.
46. Bruttmann G, Pedrali P, Arendt $C$, et al. Protective effect of cetirizine in patients suffering from pollen asthma. Ann Allergy. 1990;64(2 Pt 2):224-8.

47. Bousquet J, Emonot A, Germouty J, et al. Double-blind multicenter study of cetirizine in grass-pollen-induced asthma. Ann Allergy. 1990;65(6):504-8.

48. Dijkman JH, Hekking PRM, Molkenboer JF, et al. Prophylactic treatment of grass pollen-induced asthma with cetirizine. J Clin Exp Allergy. 1990;20(5):483-90.

49. Spector SL, Nicodemus CF, Corren J, et al. Comparison of bronchodilatory effects of cetirizine, albuterol, and both together versus placebo in patients with mild-to-moderate asthma. J Allergy Clin Immunol. 1995;96(2):174-81.

50. Weber-Schoendorfer C, Schaefer $C$. The safety of cetirizine during pregnancy. A prospective observational cohort study. Reprod Toxicol. 2008;26(1):19-23.

51. Etwel F, Djokanovic N, Moretti ME, Boskovic R, Martinovic J, Koren G. The fetal safety of cetirizine: an observational cohort study and meta-analysis. J Obstet Gynaecol. 2014;34(5):392-9.

52. Golembesky A, Cooney M, Boev R, Schlit AF, Bentz JWG. Safety of cetirizine in pregnancy. J Obstet Gynaecol. 2018:38(7):940-5.

53. Ito S, Blajchman A, Stephenson M, Eliopoulos C, Koren G. Prospective follow-up of adverse reactions in breast-fed infants exposed to maternal medication. Am J Obstet Gynecol. 1993;168(5):1393-9.

54. Powell RJ, Leech SC, Till S, Huber PA, Nasser SM, Clark AT, British Society for Allergy and Clinical Immunology. BSACl guideline for the management of chronic urticaria and angioedema. Clin Exp Allergy. 2015;45(3):547-65.

\section{Publisher's Note}

Springer Nature remains neutral with regard to jurisdictional claims in published maps and institutional affiliations.
Ready to submit your research? Choose BMC and benefit from:

- fast, convenient online submission

- thorough peer review by experienced researchers in your field

- rapid publication on acceptance

- support for research data, including large and complex data types

- gold Open Access which fosters wider collaboration and increased citations

- maximum visibility for your research: over $100 \mathrm{M}$ website views per year

At BMC, research is always in progress.

Learn more biomedcentral.com/submissions 